\title{
O znaczeniu etycznego pojmowania pracy dla przyszłości prawa pracy - na kanwie encykliki Laborem exercens
}

\section{Uwagi wstępne}

W ostatnich latach toczy się w Polsce i na świecie ożywiona dyskusja dotycząca przyszłości prawa pracy, jego funkcji i granic uprawnień pracowniczych. Ścierają się tu dwie zasadniczo odmienne koncepcje - tradycyjna, zakładająca zachowanie i wzmocnienie instrumentów chroniących sytuację pracowników oraz liberalna, zmierzająca do zmniejszenia rygorów obciążających pracodawcę, a tym samym zmniejszająca poziom ochrony pracowników ${ }^{1}$.

Często rozważany jest także problem zakresu podmiotowego prawa pracy, szczególnie w aspekcie pojawiających się coraz to nowych, bardziej wyrafinowanych form świadczenia pracy poza stosunkiem pracy ${ }^{2}$. Nie chodzi już tylko o zatrudnianie na podstawie umów cywilnoprawnych o świadczenie usług, ale także w tzw. formule samozatrudnienia czy też w innych rozbudowanych konstrukcjach podmiotowych.

Wszystko to skłania do postawienia zasadniczego pytania o znaczenie pracy w życiu człowieka, szczególnie pracy służącej uzyskiwaniu środków utrzymania. Odpowiedź na nie w dużym stopniu rzutuje na ocenę roli ustawodawstwa pracy $w$ realizacji istotnych funkcji pracy. Poszukując odpowiedzi na te pytania

* Prof. nadzw. dr hab. Teresa WYKa, Katedra Prawa Pracy, Wydział Prawa i Administracji, Uniwersytet Łódzki, 90-232 Łódź, ul. Kopcińskiego 8/12.

1 Por. m.in. E. Bielak, H. LeWandowski, Granice liberalizacji prawa pracy. Materiały z XIV Zjazdu Katedr (Zakładów) Prawa Pracy i Ubezpieczeń Społecznych, Łódź 2003; I. BoRUTA, W sprawie przyszłości prawa pracy, „Praca i Zabezpieczenie Społeczne” 2005, nr 4.

2 Por. m.in.: W. SANetra, Uwagi w kwestii zakresu podmiotowego kodeksu pracy, [w:] Prawo pracy a wyzwania XXI wieku. Księga jubileuszowa Profesora Tadeusza Zielińskiego, red. M. Matey-Tyrowicz, L. Nowacki, B. Wagner, Warszawa 2002, s. 211 i n. 
odwołamy się do społecznej nauki Kościoła, a szczególnie do jednej z najistotniejszych społecznych encyklik papieskich - Laborem exercens papieża Jana Pawła II, ogłoszonej w 1981 r. w 90. rocznicę ukazania się encykliki Rerum novarum³.

\section{Etyczne pojmowanie pracy}

Dość powszechny jest pogląd, że encyklika Laborem exercens jest „etycznym traktatem o pracy"4. Jest to bez wątpienia słuszna teza, jeśli zważy się, że etyka pracy określa stosunek osoby do osoby w związku z pracą i to, co jest dobre i złe w relacjach międzyludzkich ${ }^{5}$. A właśnie „osobowy wymiar pracy ludzkiej” przenika treść tego dokumentu. Nie chodzi w nim tylko o pracę i jej znaczenie w aspekcie technicznym, organizacyjnym czy ekonomicznym, choć i na to Jan Paweł II zwraca uwagę (LE 5), ale o pracę, która „nosi na sobie szczególne znamię człowieka i człowieczeństwa, znamię osoby działającej we wspólnocie osób - a znamię to stanowi jej wewnętrzną kwalifikację, konstytuuje niejako samą jej naturę" (LE, Wstęp).

Etyczne pojmowanie pracy - to pojmowanie jej jako dobra przypisanego człowiekowi. To człowiek jest podmiotem pracy (LE 6). Papież formułuje w związku z tym, jak to sam określa, „bardzo ważny wniosek natury etycznej” i twierdzi, że „o ile prawdą jest, że człowiek jest przeznaczony i powołany do pracy, to jednak nade wszystko praca jest dla człowieka, a nie człowiek dla pracy" (LE 6). I dalej, jeżeli chodzi o etyczne pojmowanie pracy, Autor stawia „kropkę nad i” i podkreśla, że we wniosku tym (praca jest dla człowieka, a nie człowiek dla pracy) „dochodzi prawidłowo do głosu pierwszeństwo podmiotowego znaczenia pracy przed przedmiotowym" (LE 6). Zapamiętajmy tę fundamentalną tezę, na której zasadza się etyczne znaczenie pracy, bo posłuży nam ona podczas oceniania kierunków rozwoju ustawodawstwa pracy.

Etyczne pojmowanie pracy, według Jana Pawła II, jest czymś więcej niż tylko rozumieniem jej jako służącej zaspokajaniu naturalnych potrzeb człowieka. Autor Laborem exercens nie ogranicza się do wskazywania służebnej roli pracy zapewniającej sprawiedliwą zapłatę, choć tego aspektu nie pomija (LE 19), ale bardzo mocno podkreśla, że „chodzi raczej o to, aby - może bardziej jeszcze niż dotạd

3 Tekst encykliki Laborem exercens zawarty w publikacji Encykliki Ojca Świętego Bł. Jana Pawła II, Kraków [b.r.w.], s. 7-132. Wszystkie cytaty opatrzone skrótem tytułu pochodzą z tego wydania.

4 Ks. J. Tischner, Przesłanie o człowieku i jego pracy (W związku z encykliką „Laborem exercens”), [w:] ks. J. TIschneR, Idąc przez puste błonia, Kraków 2005, s.70; por także: ks. J. MAJKA, Rozważania o etyce pracy, który w słowie wstępnym do książki pisze, że jest ona hołdem dla Autora Laborem exercens, s. 5.

5 Por.: kard. K. WoutYŁA, Elementarz etyczny, Wrocław 1982, s. 108-114; M. DudA, Etyka pracy, hasło, [w:] JAN PAWEk II, Encyklopedia nauczania społecznego, red. ks. prof. dr hab. A. Zwoliński, Radom 2005, s. 138-142. 
[podk. T.W.] uwydatnić, że praca ludzka stanowi klucz, i to chyba najistotniejszy klucz, do całej kwestii społecznej, jeżeli staramy się ją widzieć naprawdę pod kątem dobra człowieka" (LE 3). Jan Paweł II odchodzi w ten sposób od starego wzorca katolickiej etyki pracy skoncentrowanego na sprawiedliwej płacy ${ }^{6} \mathrm{i}$ odwołuje się do różnorodnych stosunków międzyludzkich, jakie w związku z pracą powstają. „Wszyscy i każdy w odpowiedniej mierze i na nieskończoną prawie ilość sposobów biorą udział w tym gigantycznym procesie, poprzez który człowiek czyni sobie ziemię poddaną; w procesie pracy" (LE 4).

Podsumujmy zatem: etyczne pojmowanie pracy to rozumienie jej jako dobra przypisanego człowiekowi i dla człowieka, które pozwala mu nie tylko zaspokajać naturalne potrzeby, lecz także uczestniczyć w różnych relacjach osobowych. Po pierwsze - chodzi o relację poprzez pracę z samym sobą, po drugie - o relację pracy (mojej pracy) z innymi ludźmi pracy, po trzecie - o relację mojej pracy dla innych i po czwarte - o relację z podmiotem zatrudniającym. Rozważmy pokrótce relacje, w które wchodzi człowiek poprzez wykonywaną pracę, posiłkując się tezami Laborem exercens.

\section{Etyczne znaczenie pracy dla człowieka pracującego}

W świetle encykliki Laborem exercens praca jest dobrem człowieka, źródłem jego godności, ale także powinności pracy, a dopiero następnie źródłem uprawnień. Jest to zarazem pewna hierarchia wartości realizowanych poprzez pracę ${ }^{7}$. Tytuł rozdziału 9. encykliki (Praca - godność osoby) jednoznacznie wskazuje na ten aspekt etycznego znaczenia pracy ${ }^{8}$. Chcąc bliżej określić znaczenie etyczne pracy, trzeba mieć przed oczyma tę właśnie prawdę, że praca jest dobrem człowieka - dobrem jego człowieczeństwa (LE 9). Jednocześnie jednak Papież przestrzega „ażeby w pracy człowiek sam nie doznawał pomniejszenia swojej godności" (LE 9).

Z godności pracy ludzkiej wypływa dla człowieka moralna powinność pracy, a także powinność pracowitości (LE 16). Warto zauważyć, że uprawnienia w związku z pracą mają, w świetle encykliki, swoje źródło w uprzednim spełnieniu powinności pracy i pracowitości. „Jeśli praca w wielorakim tego słowa znaczeniu - jest powinnością, czyli obowiązkiem, to jest ona równocześnie źródłem uprawnień po stronie człowieka pracującego" (LE 16).

6 Tak określa tradycyjny wzorzec katolickiej etyki pracy ks. J. TISCHNER, Refleksje o etyce pracy, [w:] idem, Świat ludzkiej nadziei, Kraków 2005, s. 64.

7 Szerzej: T. WYKA, W poszukiwaniu aksjologii prawa pracy - o roli encykliki „Laborem exercens” Jana Pawła II, „Monitor Prawa Pracy” 2011, nr 9, s. 456-458.

8 B. Niemiec, Godność człowieka, [w:] Jan Paweł Il: Encyklopedia nauczania społecznego, red. ks. A. Zwolıńskı, Radom 2005, s. 167-170; ks. J. KowALSKI, Znamiona godności człowieka, [w:] ks. J. Kowalskı, ks. D. Sıkorskı, ks. G. Śląak, Poznać człowieka w Chrystusie. Jan Paweł II o godności ludzkiej, Częstochowa 1983, s. 142 i n. 
Papież, wskazując na te uprawnienia głównie w części IV encykliki, zatytułowanej Uprawnienia ludzi pracy, zalicza do nich w szczególności uprawnienia indywidualne, takie jak: „posiadanie pracy” (LE 18); „sprawiedliwą zapłatę” (LE 19); prawo do ochrony pracy kobiet i macierzyństwa, prawo do bezpiecznych warunków pracy oraz prawo do wypoczynku (LE 19), jak również uprawnienia zbiorowe, tj. prawo do tworzenia związków zawodowych i prawo do strajku (LE 20). W części III encykliki, zatytułowanej Konflikt pracy i kapitału na obecnym etapie historycznym, Jan Paweł II odwołuje się do prawa pracowników do partycypacji $(\text { LE 14) })^{9}$.

\section{Etyczne znaczenie pracy w relacji z ludźmi pracy}

Istota osobowego wymiaru pracy polega nie tylko na podkreśleniu godności człowieka pracującego, lecz także na tym, że dzięki pracy nawiązuje on różne relacje z innymi ludźmi pracy, wchodzi w społeczność pracy, stając się częścią określonych wspólnot. Będą to relacje indywidualne, z poszczególnymi osobami, stanowiące owoc pracy lub powstające w związku z miejscem jej świadczenia, jak również relacje ze zbiorowością ludzi pracy.

Praca łączy ludzi dzięki owocom, które przynosi. W szczególności powstaje wówczas wspólnota wytwarzania określonego produktu (wspólnota podzielonej odpowiedzialności za wytworzony produkt), wspólnota wytworu (korzystam z „cudzego" gotowego wyrobu, świadcząc pracę dla innych), a także wspólnota konsumpcji (gotowy wyrób służy wyłącznie konsumpcji) ${ }^{10}$. W ujęciu Jana Pawła II, tak rozumiane wspólnoty ludzi pracy będą się mieściły w pojęciu pracy ujmowanej jako „działalność przechodnia”, tzn. „taka, która biorąc początek w ludzkim podmiocie, skierowana jest ku zewnętrznemu przedmiotowi, zakłada swoiste panowanie człowieka nad ziemią, z kolei zaś panowanie to potwierdza i rozwija" (LE 4). W zależności więc od tego, jaka będzie odpowiedź człowieka na cudzą pracę, będzie on występował albo w roli człowieka pracy (współtwórcy), użytkownika pracy bądź też konsumenta pracy. Są to wspólnoty zakładające ze swej istoty relacje indywidualne.

W Laborem exercens tego rodzaju wspólnoty poprzez pracę zostały przez Papieża bardzo wyraźnie wyeksponowane. „Jeżeli człowiek pracuje przy pomocy zespołu środków produkcji, to równocześnie pragnie, aby owoce tej pracy służyły jemu i drugim, oraz ażeby w procesie pracy mógł występować jako współodpowiedzialny i współtwórca warsztatu, przy którym pracuje" (LE 15).

${ }^{9}$ Szerzej: T. WYkA, Partycypacja pracownicza w świetle nauczania Jana Pawła II, [w:] Studia z prawa pracy. Księga pamiątkowa ku czci doc. J. Logi, red. Z. Góral, Łódź 2007, s. 193 i n.

10 Takie wspólnoty ludzi pracy wyróżnia ks. J. TISCHNER, Refleksje o etyce pracy..., s. 73-74; por. także: A. Szostek Mic: „Communio personarum” poprzez pracę, [W:] JAN PAWEk II, „Laborem exercens”, Tekst $i$ komentarze, Lublin 1986, s. 161-162. 
Owe relacje indywidualne między ludźmi pracy, powstające na skutek wykonywanej pracy, realizują się nie tylko przez wytwarzany produkt, także na skutek „wspólnego” miejsca wykonywania pracy. Powstaje wówczas wspólnota miejsca pracy. Jan Paweł II przywiązuje szczególne znaczenie do pracy realizowanej w takiej wspólnocie, stwierdzając już we Wstępie do Laborem exercens - przypomnijmy raz jeszcze - że „praca nosi w sobie szczególne znamię człowieka i człowieczeństwa - znamię osoby działającej we wspólnocie osób" (LE, Wstęp).

Praca we wspólnocie, razem z innymi, we wspólnym miejscu pracy wymaga od uczestników tej wspólnoty określonej postawy etycznej, wymaga „solidarności pomiędzy ludźmi pracy" (LE 8). Pojęcie solidarności odnosi się do etycznej więzi między ludźmi. Papież nawołuje do „solidarności ludzi pracy, a także do solidarności z ludźmi pracy" (LE 8). Chodzi więc o wyzwolenie postawy dla dobra wspólnego. Jak pisał kardynał K. Wojtyła jeszcze w 1969 r. w dziele Osoba i czyn, solidarny członek wspólnoty „wybiera to, co wybierają inni, albo wybiera dlatego, że inni wybierają, widząc w takim przedmiocie wyboru wartość w jakiś sposób własną"11. W Laborem exercens papież Jan Paweł II ujmuje tę ideę solidarności w pracy w następujący sposób: „Człowiek pracujący pragnie nie tylko należytej za swą pracę zapłaty, ale także uwzględniania w samym procesie produkcji takich możliwości, ażeby mógł mieć poczucie, że pracując nawet we wspólnym, pracuje zarazem - na swoim" (LE, 15). Praca we wspólnym miejscu, dla dobra wspólnego nie może prowadzić do alienacji, bo to narażałoby poczucie godności człowieka pracującego. Znaczenie etyczne pracy realizowanej we wspólnym miejscu pracy polega więc na pracy dla dobra wspólnego i jednocześnie własnego.

Jak już zaznaczyliśmy, etyczne znaczenie pracy w relacji z innymi zakłada także relacje ze zbiorowością pracowników i w ramach tych zbiorowości. Praca staje się wówczas spoiwem grup realizujących wspólne cele. Tym wspólnym celem może być współuczestnictwo w dziele tworzenia, jak również w podziale dóbr. Jan Paweł II wskazuje na pewne grupy - jak to określa „organizmy pośrednie” - które byłyby połączeniem pracy i kapitału i dążyłyby „do sobie właściwych celów poprzez lojalną i wzajemną współpracę, przy podporządkowaniu wymogom wspólnego dobra" (LE 14). Owe organizmy pośrednie służą w istocie partycypacji pracowników w zarządzaniu ${ }^{12}$.

Zbiorowościami powstającymi poprzez pracę mogą być także związki zawodowe, czyli grupy „mające na celu obronę żywotnych interesów ludzi zatrudnionych w różnych zawodach” (LE 20). Według Jana Pawła II, „organizacje tego typu są nieodzownym składnikiem życia gospodarczego [...], są one wykładnikiem walki o sprawiedliwość społeczną [...], o właściwe dobro [...], nie jest to natomiast walka przeciwko innym" (LE 20).

11 Kard. K. WoJtYŁA, Osoba i czyn, Kraków 1969, s. 296.

12 Szerzej: T. WYka, Partycypacja pracownicza..., s. 201-207; por. także: ks. F. J. Mazurek, Prawa ludzi pracy w encyklice „Laborem exercens”, [W:] JAN PAWEk II, „Laborem exercens”..., s. 179-180. 
Działalność tychże „zbiorowości” powstających w związku z pracą powinna być, zdaniem Papieża, przesiąknięta „roztropną troską o dobro wspólne” (LE 20) - etyczne znaczenie pracy będzie się wyrażać w powstawaniu i działaniu różnych form reprezentacji ludzi pracy.

\section{Etyczne znaczenie pracy jako pracy dla innych}

Z etycznego punktu widzenia relacja pracy dla kogoś jest najistotniejsza ${ }^{13}$. Praca dla kogoś jest wyrazem miłości; wiąże się z trudem, który jednak w imię miłości do drugiego człowieka jest podejmowany.

Jeżeli więc człowiek pracuje tylko dla siebie, to praca staje się „egoistycznym monologiem z samym sobą"14, natomiast pracując dla innych komunikuje się $z$ innymi. Praca zatem, podobnie jak język, jest integralną częścią komunikacji między ludźmi, jest bezsłownym dialogiem z innymi i dla innych ${ }^{15}$. $\mathrm{Ci}$ „inni”, dla których praca jest świadczona, to według Laborem exercens, najpierw rodzina. W pracy dla rodziny następuje potwierdzenie, jak to określa Jan Paweł II, osobowego wymiaru pracy ludzkiej (LE 10). Papież stawia obok siebie dwa „kręgi wartości”: pierwszy jest związany z pracą, drugi - z rodziną. Obydwa „muszą łączyć się ze sobą prawidłowo i wzajemnie przenikać” (LE 10). Według Niego, rodzina stanowi jeden z najważniejszych układów odniesienia, wedle których musi być kształtowany społeczno-etyczny porządek pracy ludzkiej (LE 10).

Praca dla własnej rodziny jest jednocześnie pracą dla „,wielkiego społeczeństwa, do którego człowiek przynależy na podstawie szczególnych więzi kultury i historii” (LE 10), a więc jest pracą dla narodu. Tożsamość narodowa człowieka powoduje, że „pracę swoją pojmuje także jako pomnożenie dobra wspólnego wypracowywanego przez rodaków, a także jako dorobek całej rodziny ludzkiej" (LE 10).

Etyczny wymiar pracy wyraża się więc $w$ tym szczególnym celu, dla którego praca jest podejmowana, tj. w celu uzyskiwania środków utrzymywania, czyli w pracy dla kogoś, dla najbliższych członków rodziny, dla wspólnie pracujących, dla narodu, dla świata. Jak konstatuje Autor Laborem exercens: „Ostatecznie bowiem celem pracy: jakiejkolwiek pracy spełnianej przez człowieka - choćby była to praca najbardziej służebna, monotonna [...], pozostaje zawsze sam człowiek" (LE 6).

„Praca dla kogoś jest zatem moralną powinnością człowieka. Człowiek powinien więc pracować nie tylko ze względu na swoje własne człowieczeństwo, którego utrzymanie i rozwój domaga się pracy [...], ale także ze względu na bliźnich, zwłaszcza ze względu na swoją rodzinę, ale także ze względu na całą rodzinę ludzką, której jest członkiem będąc dziedzicem pracy pokoleń, a zarazem współtwórcą przyszłości tych, którzy po nim nastaną w kolei dziejów" (LE 16).

${ }^{13}$ Ks. J. TISChner, Przesłanie..., s. 84.

14 Ibidem, s. 86.

${ }^{15}$ Ks. J. TISChner, Refleksje..., s. 73. 


\section{Etyczne znaczenie pracy w relacjach z podmiotem zatrudniającym}

Realizacja etycznego celu pracy - pracy dla kogoś - może się dokonywać w różnych formach. Może to być praca na własny rachunek, ale może to być także praca na rzecz podmiotu zatrudniającego. W tym ostatnim przypadku człowiek pracujący wchodzi w relację z podmiotem go zatrudniającym. Także te relacje powinny mieć wymiar etyczny. Zauważmy jednak na początku, że realizacja osobowego wymiaru pracy - tj. potwierdzenie i uzyskanie godności, praca z innymi i dla innych nie wymaga podmiotu zlecającego. Jeśli jest, tzn. jeśli powstaje stosunek zatrudnienia, to w tym stosunku ten, kto zatrudnia, pełni rolę służebną wobec tego, kto pracę świadczy. Istnieje on bowiem tylko o tyle, o ile człowiek zechce realizować swoje człowieczeństwo poprzez pracę w tej właśnie formie. Nie ma więc zatrudniającego czyli pracodawcy w szerokim tego słowa znaczeniu, jeżeli nie ma człowieka pracującego na rzecz innego podmiotu, natomiast może być tylko sam człowiek pracujący, by zrealizować etyczny wymiar pracy.

Mając więc na uwadze tę służebną rolę podmiotu zatrudniającego w etycznym wymiarze pracy, zwróćmy najpierw uwagę, że tę rolę służebną w stosunku zatrudnienia pełni zarówno pracodawca bezpośredni, jak i pośredni. W świetle Laborem exercens, „pracodawcą bezpośrednim jest [...], osoba lub też instytucja, z którą pracownik zawiera bezpośrednio umowę o pracę [...], natomiast przez pracodawcę pośredniego należy rozumieć wiele zróżnicowanych czynników [...], wywierających określony wpływ na to, w jaki sposób kształtuje się umowa o pracę, a w konsekwencji mniej lub bardziej sprawiedliwie stosunku w dziedzinie pracy ludzkiej" (LE 16).

Według Jana Pawła II, zasadnicza rola pracodawcy (bezpośredniego i pośredniego) polega na ponoszeniu odpowiedzialności za zapewnienie owych sprawiedliwych stosunków w pracy. Odpowiedzialność pracodawcy pośredniego, którym jest przede wszystkim państwo (LE 17), jest wprawdzie „mniej bezpośrednia - ale pozostaje odpowiedzialnością merytoryczną: pracodawca pośredni określa w sposób zasadniczy taki lub inny aspekt stosunku pracy i warunkuje w ten sposób postępowanie pracodawcy bezpośredniego [...]. Stwierdzenie takie nie ma na celu uwolnienia tego ostatniego od właściwej mu odpowiedzialności, ale tylko zwrócenie uwagi na cały splot uwarunkowań, które wywierają wpływ na jego postępowanie" (LE 17).

Jak z tego wynika, dla zapewnienia realizacji etycznego wymiaru pracy państwo jako pracodawca pośredni pełni rolę pierwszoplanową - ponosi odpowiedzialność za kształt prawidłowych relacji między pracownikiem a pracodawcą bezpośrednim; ponosi odpowiedzialność za „urzeczywistnianie uprawnień człowieka pracy [...], które nie mogą być tylko pochodną systemów ekonomicznych" (LE 17). 
Zakłócenie prawidłowych, z etycznego punktu widzenia, relacji między pracodawcą a pracownikiem najczęściej przybiera postać wyzysku. Nie chodzi tu tylko o wyzysk ekonomiczny, gdy praca nie jest sprawiedliwie wynagradzana, lecz także o wyzysk moralny, który zachodzi wówczas, gdy praca jest oderwana od celów etycznych ${ }^{16}$. Sprzyja mu w szczególności daleko posunięty podział pracy, gdy łatwo oddzielić produkt od wartości, którym ma służyć, pozostawiając człowieka pracującego w stanie bezsilności i niewiedzy ${ }^{17}$. W Laborem exercens problem wyzysku jest podejmowany w kilku miejscach. Jan Paweł II zwraca na to uwagę, pisząc o sprawiedliwości społecznej i solidarności ludzi pracy. „Solidarność taka winna występować stale tam, gdzie domaga się tego społeczna degradacja podmiotu pracy, wyzysk pracujących i rosnące obszary nędzy" (LE 8). Wyzyskiwani, nazywani przez Jana Pawła II „ubogimi”, pojawiają się „jako wynik naruszenia godności ludzkiej pracy bądź przez [...], klęskę bezrobocia, bądź przez to, że zaniża się wartość pracy i prawa, jakie z niej wynikają" (LE 8).

\section{Wnioski}

Przedstawione etyczne rozumienie pracy w ujęciu encykliki Laborem exercens, która jest źródłem wartości istotnych dla prawa pracy ${ }^{18}$, może posłużyć do oceny i nakreślenia kierunków zmian prawa pracy.

Po pierwsze, wykonywana przez człowieka praca jest źródłem jego godności niezależnie od podstawy (formy) jej świadczenia i zasługuje na ochronę, jeśli w szczególności jest wykonywana dla innych w celu uzyskiwania środków utrzymania. Nie bez powodu Jan Paweł II posługuje się w Laborem exercens najczęściej pojęciem „Iudzi pracy”, „człowieka pracującego”, a nie wyłącznie pojęciem „pracownik”, chcąc podkreślić etyczny wymiar każdej pracy bez względu na podstawę. Czy nie powinien więc z tego wypływać wniosek, że prawo pracy nie może być prawem egoistycznym i obejmować ochroną tylko tych, którzy świadczą pracę w ramach stosunku pracy? Powinno dotyczyć wszystkich tych, którzy świadczą pracę w słusznym celu. To podmiotowość osoby pracującej powinna decydować o włączeniu jej w zakres prawa pracy, a nie forma świadczenia pracy, która z etycznego punktu widzenia jest drugorzędna. Czym różni się godność człowieka, który świadczy pracę w ramach stosunku pracy od godności pracującego np. na podstawie umów cywilnoprawnych? Z jakich powodów ten ostatni jest pozbawiony ochrony? Paradoks dzisiejszych czasów i „egoizm” prawa pracy powoduje, że to właśnie te osoby pozbawione bardziej niż „pracownicy” swojej godności w upokarzających formułach prawnych, zasługują na szczegól-

\footnotetext{
16 Ks. J. Tischner, Refleksje..., s. 78.

17 Ks. J. Tischner, Wobec wartości, Poznań 2001, s. 93-95.

18 Por. T. WYKA, W poszukiwaniu..., s. 454 i n.
} 
ną ochronę. W ramach ochrony, jaką powinno gwarantować państwo w związku z pracą należy uwzględniać nie tylko ochronę zdrowia i życia pracujących, co już w pewnym stopniu jest zapewnione ${ }^{19}$, lecz także ochronę w zakresie szeroko rozumianego prawa do wypoczynku i ochronę przed wyzyskiem ekonomicznym i moralnym.

Po drugie, etyczne rozumienie pracy zakłada pracę realizowaną z innymi, we wspólnocie. Czy w związku z tym prawo pracy nie powinno w większym stopniu uwzględniać relacji poziomych, w jakie wchodzą pracownicy między sobą, czy nie powinno ustalać ich wzajemnych praw i obowiązków? Jak dotąd bowiem, prawo pracy jest skupione na regulowaniu relacji pionowych zachodzących między pracodawcą i pracownikiem, zubożając zasadniczo stosunki interpersonalne powstające w związku z pracą, we wspólnym miejscu pracy. Regulacje określające relacje między pracownikami służyłyby także uświadomieniu większej odpowiedzialności za innych i dobro wspólne.

Po trzecie, istotnej weryfikacji w ramach prawa pracy wymaga pozycja i rola pracodawcy pośredniego w zapewnieniu ekonomicznego i etycznego ładu w pracy. Jeśli dzięki pracy następuje zaspokojenie istotnych potrzeb społecznych, które w szczególności uosabia rodzina, to państwo (czyli pracodawca pośredni) nie może tychże potrzeb społecznych pozostawiać do realizacji pracodawcy bezpośredniemu. Czy zatem w prawie pracy nie należałoby znacznie szerzej określić rolę państwa w realizacji uprawnień i powinności powstających w związku z pracą. Daleko niewystarczające jest zapewnienie jedynie nadzoru państwa nad wykonywaną pracą (art. 24 konstytucji).

Jeśli uznamy, że autorytet prawa pracy podnosi zapewnienie człowiekowi pracującemu jego „godności, wspólnoty braterskiej i wolności”, do których to wartości odwołuje się Jan Paweł II w zakończeniu encykliki Laborem exercens (LE 27), to postulujmy zmiany w modelu.

Nowy paradygmat prawa pracy powinien wyrażać się w tym, że jeśli tylko praca spełnia ów wymiar etyczny (jest potwierdzeniem godności, uczestnictwa we wspólnocie ludzi pracy, dla zaspokajania potrzeb własnych i innych) to zasługuje na odpowiednią, sprawiedliwą ochronę.

Przyszłość prawa pracy należy więc upatrywać bardziej w poszerzeniu jego zakresu podmiotowego i wyrównywaniu szans wszystkich ludzi pracy w korzystaniu z uprawnień w związku z pracą, niż w jego liberalizacji na rzecz pracodawców bezpośrednich, którzy w etycznym pojmowaniu pracy pełnią wyłącznie rolę służebną, i w tej roli powinni być istotnie wspomagani przez państwo, jako pracodawcę pośredniego.

19 T. WYKA, Konstytucyjne prawo każdego do bhp a zatrudnienie na innej podstawie niż stosunek pracy oraz praca na własny rachunek - uwagi de lege ferenda, „Gdańskie Studia Prawnicze” 2007, vol. XVII, s. 331 i n. 